\title{
BMJ Open Does mothers' pregnancy intention affect their children's preventive and curative care in India? Evidence from a longitudinal survey
}

\author{
Poulomi Chowdhury (D) , ${ }^{1}$ Mausam Kumar Garg, ${ }^{2}$ Md Illias Kanchan Sk (D) ${ }^{3}$
}

To cite: Chowdhury P, Garg MK, Kanchan Sk Ml. Does mothers' pregnancy intention affect their children's preventive and curative care in India? Evidence from a Iongitudinal survey. BMJ Open 2021;11:e042615. doi:10.1136/ bmjopen-2020-042615

- Prepublication history for this paper is available online. To view these files, please visit the journal online (http://dx.doi. org/10.1136/bmjopen-2020042615).

Received 15 July 2020 Revised 16 March 2021 Accepted 22 March 2021

Check for updates

(C) Author(s) (or their employer(s)) 2021. Re-use permitted under CC BY-NC. No commercial re-use. See rights and permissions. Published by BMJ.

${ }^{1}$ Institute of Health, University of Canberra, Canberra, Australian Capital Territory, Australia ${ }^{2}$ Department of Migration and Urban studies, International Institute for Population Sciences, Mumbai, Maharashtra, India ${ }^{3}$ EMS\&DE, International Institute for Population Sciences, Mumbai, Maharashtra, India

Correspondence to

Poulomi Chowdhury; poulomi378@gmail.com

\section{ABSTRACT}

Objective To assess the effect of unintended births on preventive and curative care of children and their nutritional status.

Design The study uses a cross-sectional prospective design.

Setting Indian Human Development Survey (IHDS) data of two rounds were used in this study. Women data file was used to draw a representative sample of 3905 children who belong to under 5 years of age group.

Statistical analyses We categorised birth as an unintended birth if the mother did not want to have an additional child at IHDS-I but gave birth during the intersurvey. Furthermore, all births exceeding to the desired number of children reported by mothers in the IHDS-II were also included in unintended births. Multivariate logistic regression models were applied to analyse the effect of unintended births on child immunisation and exclusive breast feeding, while multivariate linear regression models were used to assess the effect of childbearing intention on child nutritional status.

Results The study shows that by controlling other factors, children from unintended births were less likely to be exclusively breast fed (OR $0.885,95 \% \mathrm{Cl} 0.792$ to 0.990 , $\mathrm{p}<0.05)$ and receive full immunisation (OR $0.830,95 \% \mathrm{Cl}$ 0.739 to $0.931, \mathrm{p}<0.001)$. Moreover, poor nutrition was more prevalent among children from unintended births as they were more likely to be stunted and underweight. Conclusions The study confirmed the adverse effects of unintended pregnancy on children's preventive and curative care. The findings of the study underscore the importance of formulating policies on more affordable, accessible and available means of family planning to reduce the unintended births.

\section{INTRODUCTION}

Unintended pregnancies are those pregnancies which occur at the time of conception, which are either mistimed or unwanted. In other words, these are those pregnancies which eventuated without the desire of having any or more children. Further, pregnancies can be categorised as mistimed when they occur more untimely than desired. ${ }^{1}$ Moreover, pregnancy is an important factor leading to high fertility rates in many
Strengths and limitations of this study

- The findings of this study are from a nationally representative sample of 3905 children who belong to under 5 years of age group.

- Other child development indicators, namely cognitive skills and academic performance, are not included in this study.

- The 7-year duration between the survey period could have changed women's childbearing intention.

developing countries including India. ${ }^{2-6}$ It marks the serious socioeconomic and health consequences for women and their families. ${ }^{7}$ Gipson et $a l \mathrm{~s}^{7}$ study emphasises on the effect of unintended pregnancy in several phases viz. (1) maternal behaviour during pregnancy, (2) birth outcomes, (3) maternal postpartum behaviour, and (4) infant and child health. Studies on developed countries show the positive relation between unintended pregnancies and maternal risk behaviour involving alcohol consumption, smoking, drug use and caffeine intake, ${ }^{89}$ while studies on developing countries show the inconsistent result. Some studies have reflected the significant positive association between unintended pregnancy and antenatal or delivery care, ${ }^{10}{ }^{11}$ and other studies have found no association. ${ }^{12} 13$ Compared with developed nations, the developing countries have high occurrence of poor antenatal or delivery care among women with unintended pregnancy. ${ }^{7}$ It is observed that out of 213 million pregnancies worldwide, $40 \%$ of them were unintended. ${ }^{14}$ Further, half of the unplanned births ended up in induced abortion, ${ }^{14}$ which is not safe in many countries that have restricted abortion laws. Due to unsafe abortion, women tend to face serious complications like haemorrhage (heavy bleeding), incomplete abortion (failure to remove all of the pregnancy tissue from uterus), infection, 
urine perforation, and damaged genital tract and internal organs. ${ }^{15}$ Subsequently, unintended pregnancies often result in unplanned births and miscarriages. Therefore, preventing unintended pregnancies is important in achieving the United Nations Sustainable Development Goals, that is, improving maternal and child mortality (goals 3.1 and 3.2, respectively).

It is observed from various studies that children born from unintended pregnancies suffer from various social and health problems. The mothers of the children did not take adequate prenatal care ${ }^{1617}$ and did not provide proper immunisation. They do not even give proper exclusive breast feeding or refrain from doing so, ${ }^{18}$ resulting to poorer physical health of their children than those who are intended. ${ }^{16}$ Children from unintended pregnancies are associated with 1.41 times odds of having low birth weight as well as high risk of prematurity. ${ }^{19}$ Likewise, they have less close mother-child relationship and poorer educational and behavioural outcomes. ${ }^{20}$

India is the second most populous country in the world with a population of 1.3 billion. The National Family and Health Survey (NFHS-4) conducted in 2015-2016 report reflects that around $35.8 \%$ of children under 5 years are underweight and $58.6 \%$ are anaemic. The percentage of underweight children varies differently across the states. It is highest in Bihar (43.9\%), Jharkhand (47.8\%) and Madhya Pradesh (42.8\%), and lowest in Mizoram (12\%), Manipur (13.8\%) and Sikkim (14.2\%). The prevailing poor health status of children in the country may become more cumbersome when unintended births come into the picture. Following the $21 \%$ unintended pregnancies as per the NFHS-3 (2005-2006), it would be very important to study its associated effect on children's health. Recently, based on retrospective and prospective data of India, it is observed that unintended pregnancies have adverse effects on childhood vaccination and stunting. ${ }^{61}$ Further, there are no current studies which have worked on the national level considering all the states of India, and most research examining correlates of the intention status of women's pregnancies in India has been based on data collected from cross-sectional surveys and by using prospective fertility intentions. Moreover, these studies do not provide the current scenario of unintended births. Therefore, this study analyses the effect of unintended births (measured using prospective approach) on preventive and curative care of children in India using nationally representative cross-sectional data.

\section{METHODS}

\section{Study design}

The quantitative approach has been used for this study. It focuses on unintended births and associated child health outcomes. Further, to give emphasis on unintended births at national level, the cross-sectional data are the suitable option.

\section{Data source}

The present study used data from two rounds of the Indian Human Development Survey (IHDS), conducted

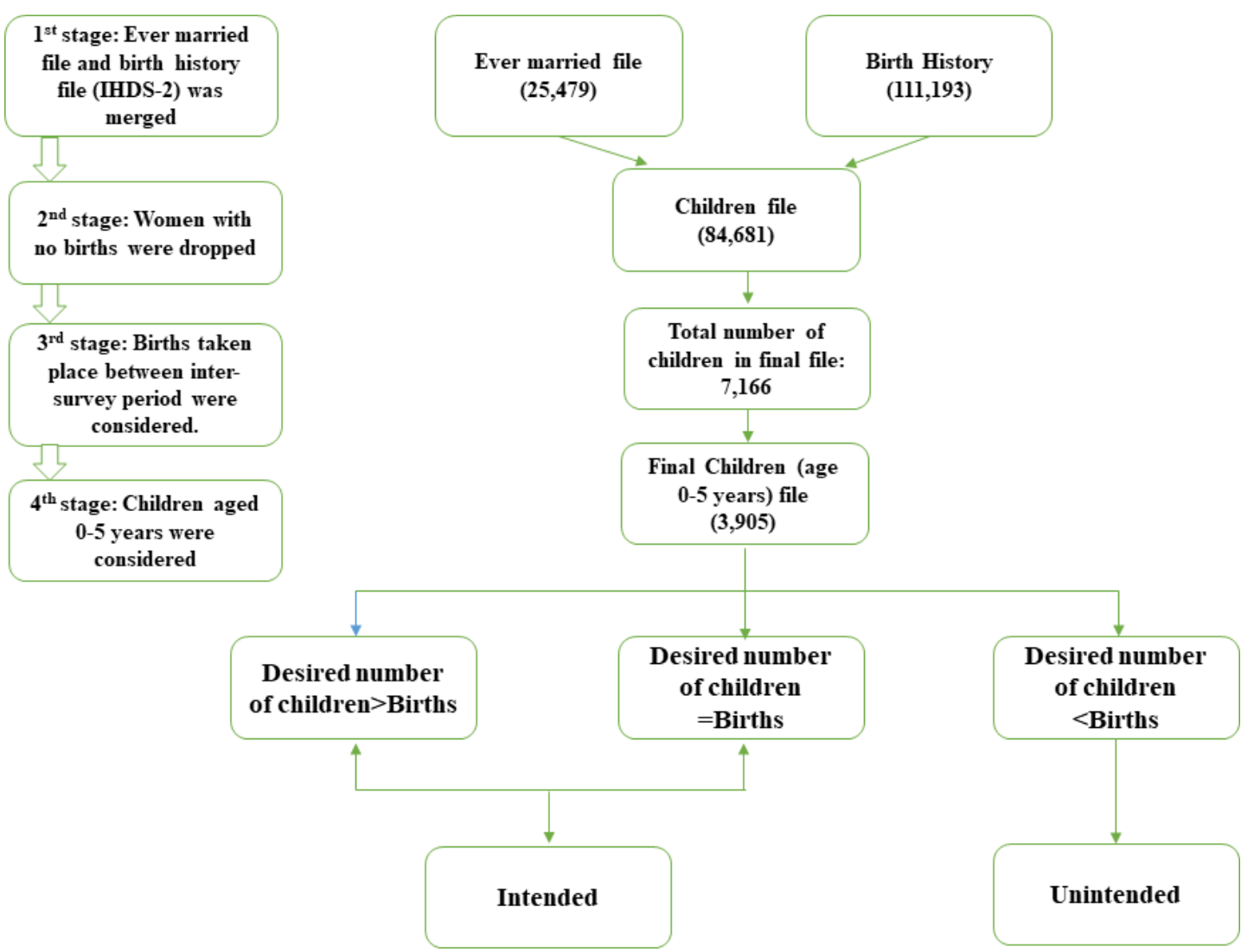

Figure 1 Sample selection procedure. IHDS, Indian Human Development Survey. 


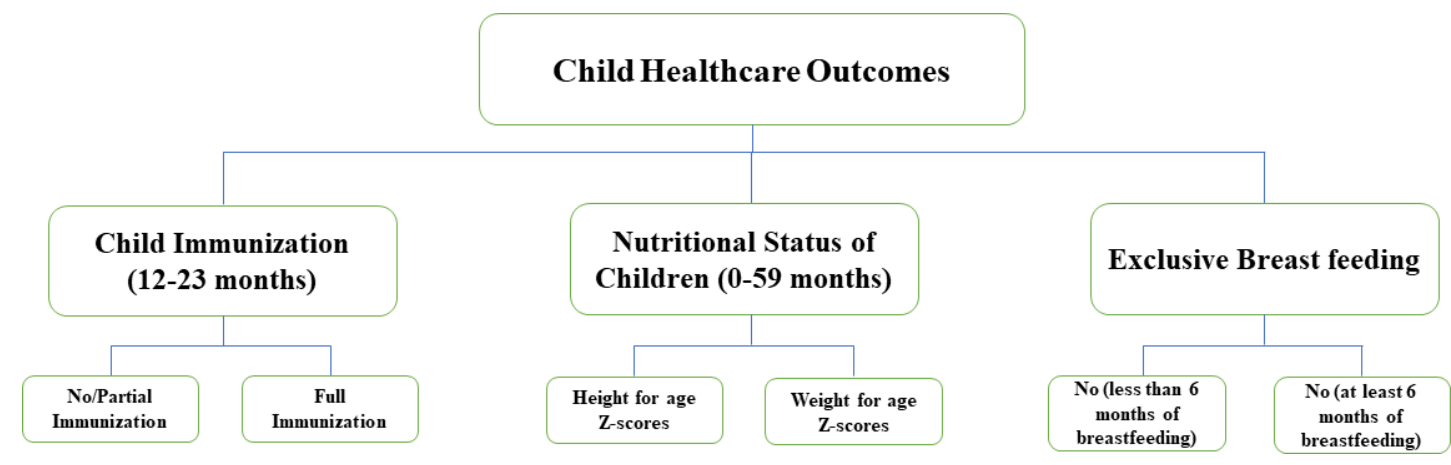

Figure 2 Child healthcare and growth-related outcomes.

during 2004-2005 and 2011-2012. IHDS covered 41554 households in round 1 and 42152 households in round 2. IHDS is a nationally representative survey which provides data on different topics such as health, education, employment, economic status, marriage, fertility, gender relations and social capital. The data of completed short reading, writing and arithmetic tests of children aged $8-11$ years are also available. ${ }^{22}$

For this study, the women data files from two rounds of IHDS were linked together. A total number of women accounted for 25479 who were available in both rounds were considered for the analysis. Then, children file was created by combining ever-married file with birth history file. Here, only those births which had taken place between the intersurvey periods were taken into account. Furthermore, women who have given birth to two or more children during the intersurvey period were also included. On the other hand, women who had experienced miscarriage/abortion/neonatal mortality during the intersurvey period were excluded from the study. Thus, after filtering all the sample size, it reduces to 7166 children and out of them, 3905 belong to under age 5 years with the information in all variables of interest including anthropometric measures. The procedure of sample selection is presented in the following figure 1 .

\section{Outcome variables}

In the present paper, child healthcare and growth outcomes are taken as child immunisation, exclusive breast feeding and nutritional status (figure 2). The child immunisation was calculated using four vaccines: BCG; diphtheria, tetanus, pertussis (1-3 years); polio (1-3 years) and measles for children aged 12-23 months. Only those children who received all four vaccines were considered fully immunised. ${ }^{23}$ In case of breast feeding, only those children who have received it for at least the first 6 months without any supplementary food were considered exclusively breast fed. ${ }^{24}$ The nutritional status of children under age 5 years is calculated using STATA macro file provided by ${ }^{25}$. This STATA macro file calculates the height-for-age z-scores (HAZ) and weight-for-age z-scores (WAZ) for the children.

\section{Measurement of childbearing intention}

All births to women who reported that they did not want to have an additional child in the first round (IHDS-I) but gave birth during the intersurvey period were classified as unintended births. If the woman wanted to have an additional child in the first round, she was further asked how many did she want. These children are referred as the desired number of additional children and were

Table 1 Process of calculating unintended births

\begin{tabular}{|c|c|c|c|c|c|c|c|}
\hline $\begin{array}{l}\text { Women ID } \\
\text { (C1) }\end{array}$ & $\begin{array}{l}\text { Birth } \\
\text { order in } \\
\text { round } 2 \\
\text { (C2) }\end{array}$ & $\begin{array}{l}\text { Do you want to have } \\
\text { any more children in } \\
\text { addition to the child } \\
\text { you are now carrying } \\
\text { (round 1)? } \\
\text { (C3) }\end{array}$ & $\begin{array}{l}\text { Number of additional } \\
\text { children desired in } \\
\text { addition to the child you } \\
\text { are now carrying (round 1) } \\
\text { (C4) }\end{array}$ & $\begin{array}{l}\text { Number of } \\
\text { births in } \\
\text { round } 1 \\
\text { (C5) }\end{array}$ & $\begin{array}{l}\text { Total number } \\
\text { of desired } \\
\text { children in } \\
\text { round } 1 \\
(\mathrm{C} 6=\mathrm{C} 4+\mathrm{C} 5)\end{array}$ & $\begin{array}{l}\text { Number of } \\
\text { unwanted } \\
\text { children } \\
\text { (C7=C2-C6) }\end{array}$ & $\begin{array}{l}\text { Unintended } \\
\text { births } \\
\text { (if C7 >0) } \\
\text { (C8) }\end{array}$ \\
\hline 1 & 3 & Yes & 1 & 2 & 3 & 0 & No \\
\hline 1 & 4 & Yes & 1 & 2 & 3 & 1 & Yes \\
\hline 3 & 3 & Yes & 1 & 2 & 3 & 0 & No \\
\hline 4 & 1 & No & 0 & 0 & 0 & 1 & Yes \\
\hline 4 & 2 & No & 0 & 0 & 0 & 2 & Yes \\
\hline 5 & 3 & No & 0 & 2 & 2 & 1 & Yes \\
\hline 6 & 1 & Yes & 2 & 0 & 2 & -1 & No \\
\hline
\end{tabular}




\section{Table 2 Background characteristics of children aged 0-5 years $(\mathrm{N}=3905)$}

\begin{tabular}{|c|c|}
\hline Background characteristics & Percentage \\
\hline \multicolumn{2}{|l|}{ Birth Intention } \\
\hline Intended & 37.32 \\
\hline Unintended & 62.68 \\
\hline \multicolumn{2}{|l|}{ Children survival } \\
\hline $1-2$ & 19.87 \\
\hline 3 & 51.98 \\
\hline $4+$ & 28.14 \\
\hline
\end{tabular}

\section{Sex of the child}

Male $\quad 43.15$

Female

56.85

\begin{tabular}{|c|c|}
\hline \multicolumn{2}{|l|}{ Caste groups } \\
\hline General & 21.46 \\
\hline Other backward caste & 39.92 \\
\hline Scheduled Caste & 26.33 \\
\hline Scheduled Tribe & 11.29 \\
\hline No caste & 1.00 \\
\hline \multicolumn{2}{|l|}{ Religion } \\
\hline Hindu & 74.96 \\
\hline Muslim & 20.82 \\
\hline Others & 4.23 \\
\hline \multicolumn{2}{|l|}{ Mother's education } \\
\hline No education & 54.29 \\
\hline Primary & 14.98 \\
\hline Secondary & 23.35 \\
\hline Higher & 7.38 \\
\hline \multicolumn{2}{|l|}{ EAG states } \\
\hline Non-EAG & 36.31 \\
\hline EAG & 63.69 \\
\hline \multicolumn{2}{|l|}{ Place of residence } \\
\hline Rural & 75.90 \\
\hline Urban & 24.10 \\
\hline
\end{tabular}

Exclusive breast feeding

\begin{tabular}{lc} 
No & 68.72 \\
Yes & 31.28 \\
Full immunisation (12-23 months) & \\
No & 76.60 \\
Yes & 23.40 \\
\hline
\end{tabular}

EAG, Empowered Action Group.

matched with their mothers' actual number of children born during the intersurvey period. The number of births exceeding the desired number of children reported by women was classified as unintended births. Remaining births were classified as intended births. The process of calculation is presented in table 1 .

\section{Other independent variables}

The socioeconomic and demographic variables in this study include the number of children survived $(0-2,3-4$, $4+$ ); sex of the child (male, female); religion (Hindu, Muslim, Others); caste groups (forward caste/general, other backward caste (OBC), Scheduled Caste (SC), Scheduled Tribe, no caste) (The caste variable was divided into four hierarchically ranked groups based on the access to wealth, power and privilege, namely: (1) general/forward caste, (2) OBC, (3) SC, and (4) Scheduled Tribe); mother's education (educational attainment was classified into four groups, that is, (1) no education (no formal education and below primary), (2) primary (standard 1-5), (3) secondary (standard 6-10), (4) higher (standard 11 and above)); place of residence (rural, urban); Empowered Action Group (EAG) states (non-EAG, EAG) (EAG referred to eight economically backward states of India, where the demographic transition and infant mortality rate indicators are poor. These are Bihar, Uttar Pradesh, Madhya Pradesh, Jharkhand, Chhattisgarh, Rajasthan, Odisha and Uttarakhand.); and wealth index (low, medium, high).

\section{Patient and public involvement \\ No patient involved.}

\section{Statistical analysis}

We employed bivariate with $\mathrm{X}^{2}$ test and multivariate analyses to accomplish the study objectives. A multivariate logistic regression model was applied to analyse the effect of unintended and intended childbearing on child immunisation and exclusive breast feeding after controlling other socioeconomic and demographic variables. For this purpose, both outcome variables were classified in binary form as fully immunised ( $1=y e s, 0=$ no) and exclusively breast fed $(1=y e s, 0=$ no). Further, to assess the effect of childbearing intention on child nutritional status, linear regressions were applied using HAZ and WAZ as outcome variables and other socioeconomic and demographic variables as independent variables. The whole analysis was performed using STATA V.13.

\section{RESULTS}

Table 2 provides the background information of children aged $0-5$ years. Out of the total number of children aged $0-5$ years, $62.6 \%$ children were unintended. Nearly, $56.8 \%$ of them were female children while $43.2 \%$ were male. Most of these belonged to OBC and SC groups, while in terms of religion most of them were from Hindu religious groups. More than half of the children's mothers had no education, whereas only $7.3 \%$ had completed higher studies. Further, less than half of them received exclusive breast feeding and full immunisation.

Nearly $68 \%$ of children from intended births and $57 \%$ of children from unintended births were fully immunised (table 3). These differences were statistically significant $(\mathrm{p}<0.001)$. Moreover, around $32.9 \%$ of children from 
Table 3 Child healthcare outcomes by birth intention reported by mothers

\begin{tabular}{|c|c|c|c|c|}
\hline Birth intention & $\begin{array}{l}\text { Full immunisation* } \\
\text { (percentage) }^{\star * \star}\end{array}$ & $\begin{array}{l}\text { Exclusive breast feeding* } \\
{\text { (percentage })^{\star \star \star}}^{*}\end{array}$ & $\begin{array}{l}\text { Z-score for height for aget } \\
\text { (mean) }{ }^{\star *}\end{array}$ & $\begin{array}{l}\text { Z-score for weight for age } \\
\text { (mean) }\end{array}$ \\
\hline Intended & 68.1 & 32.9 & -1.75 & -1.14 \\
\hline
\end{tabular}

${ }^{\star * \star} \mathrm{P}<0.01,{ }^{* *} \mathrm{p}<0.05$.

*Differences by birth intention were tested by performing $\mathrm{X}^{2}$ test.

†Differences by birth intention were tested by performing a $z$ test.

intended births in contrast to $29.9 \%$ of children from unintended births were exclusively breast fed $(\mathrm{p}<0.05)$. Further, a higher mean value of HAZ $(-1.75)$ was seen among children from intended births as compared with -2.11 among those from unintended births. Mean WAZ was significantly lower among children from unintended births $(-1.49)$ as compared with those from intended births $(-1.14)$.

The result reveals that the odds of child immunisation and exclusive breast feeding reduced by $0.165(\mathrm{p}<0.001)$ and $0.109(\mathrm{p}<0.05)$ times, respectively, if the child was unintended (table 4). Mothers having four and above children survived were less likely to receive full immunisation compared with others. Similarly, children from a Muslim community were less likely to receive full immunisation and exclusive breast feeding compared with other communities. However, the children of educated mothers with better wealth condition were more likely to receive full immunisation than their counterparts. Moreover, the odds of exclusive breast feeding were $0.291 \quad(p<0.001)$ times lower among those living in EAG states in comparison with those who were living in non-EAG states. As far as caste of the children is concerned, children who belonged to Scheduled Tribe and SC were less likely to receive full immunisation as compared with children from forward/general caste.

Table 5 shows the determinants of child malnutrition. After controlling other factors, unintended children had significantly lower HAZ $(-0.193, \mathrm{p}<0.05)$ and WAZ $(-0.172, \mathrm{p}<0.05)$. However, scores were increased with mother's education and household's wealth index. Children who belonged to SC $(-0.205, \mathrm{p}<0.05)$ and Scheduled Tribe $(-0.267, \mathrm{p}<0.05)$ had lower HAZ as compared with children from general caste.

\section{DISCUSSION}

The present study sheds light on adverse health outcomes of children born as unintended births using a prospective approach. In India, a country which has the highest number of underweight children with anaemia, the presence of unintended birth will more likely worsen the child's physical and psychological development. Singh et $a l^{21}$ in their study mentioned that each year there are estimated 26 million births in India. If one-fifth of all births are unintended every year, then at least some children will suffer from adverse health outcomes, which is also likely to be seen in our study that unintended children are less likely to be exclusively breast fed and receive full immunisation. The present finding is similar to previous studies which suggest that unintended pregnancy is associated with late initiation of prenatal care and inadequate childhood vaccination. ${ }^{13} 16172627$ The present analysis vividly brings out the fact that children who were reported as unintended are more likely to be stunted and underweight, while previous studies only reported that children from unintended births are significantly more likely to be stunted than those who are intended. ${ }^{202} 28$ This work has examined the association between unintended births assessed prospectively and poor child growth using the longitudinal dataset for all India.

The tendency of low exclusive breast feeding and full immunisation among unintended children reflects that women are not giving proper care to their children even from the early stages of their life. One reason could be the less emotional attachment from mother to their children as they are unintended. In the present study, the likelihood of full immunisation, exclusive breast feeding, WAZ and HAZ are not significant for female children. The maltreatment of female children has been a very common phenomenon throughout India as it is believed that female children are a burden to the family. This is also the reason for low sex ratio and child ratio in the country. Further, it is an unavoidable truth that female feticide and undernourished female children are quite prevalent in major parts of the country. ${ }^{28-30}$ Moreover, the above result shows the likelihood of children's health reducing with more number of children, which simply reflects that a mother could not be able to take care of her next kin if she already has two or more children. Further, taking care of more than two children is very difficult socially and economically. Therefore, with growing living cost and education cost, people in India are becoming more sceptical about intending another child, resulting in comparatively low total fertility rate (TFR) in the country. The recent report of NFHS-4 shows that the current TFR of India is 1.8, which has reduced from 2.1 in NFHS-3. Therefore, it is quite likely that unintended children who belong to rural areas and with low economic background are more likely to have poor health conditions. Moreover, it is mentioned in several studies that poor physical development of children may hinder their cognitive ability, which also results in poor academic performance 
Table 4 ORs (with 95\% Cls) from multivariate regression analyses examining associations between selected characteristics and child immunisation and exclusive breast feeding

\begin{tabular}{|c|c|c|}
\hline Covariates & Child immunisation & Exclusively breast fed \\
\hline \multicolumn{3}{|l|}{ Birth intention } \\
\hline \multicolumn{3}{|l|}{ Intended† } \\
\hline Unintended & $0.835^{\star \star \star}(0.739$ to 0.931$)$ & $0.891^{\star \star}(0.792$ to 0.990$)$ \\
\hline \multicolumn{3}{|l|}{ Children survival } \\
\hline \multicolumn{3}{|l|}{$1-2^{\dagger}$} \\
\hline $3-4$ & 1.005 (0.898 to 1.240$)$ & 1.141 (0.973 to 1.309$)$ \\
\hline $4+$ & $0.693^{\star \star \star}(0.563$ to 0.824$)$ & 1.111 (0.904 to 1.319$)$ \\
\hline \multicolumn{3}{|l|}{ Sex of the child } \\
\hline \multicolumn{3}{|l|}{ Male $^{\dagger}$} \\
\hline Female & 1.02 (0.908 to 1.132$)$ & 0.951 (0.848 to 1.054$)$ \\
\hline \multicolumn{3}{|l|}{ Caste groups } \\
\hline \multicolumn{3}{|l|}{ General $^{\dagger}$} \\
\hline Other backward caste & 1.003 (0.849 to 1.158$)$ & 1.096 (0.938 to 1.254$)$ \\
\hline Scheduled Caste & $0.775^{\star \star}(0.637$ to 0.914$)$ & 0.941 (0.783 to 1.100$)$ \\
\hline Scheduled Tribe & $0.723^{\star \star}(0.567$ to 0.879$)$ & 1.135 (0.895 to 1.375$)$ \\
\hline No caste & 0.823 (0.387 to 1.259$)$ & 1.756 (0.890 to 2.623$)$ \\
\hline \multicolumn{3}{|l|}{ Religion } \\
\hline \multicolumn{3}{|l|}{$\mathrm{Hindu}^{\dagger}$} \\
\hline Muslim & $0.648^{\star * \star}(0.549$ to 0.747$)$ & $0.658^{\star \star \star}(0.556$ to 0.761$)$ \\
\hline Others & 0.973 (0.654 to 1.292$)$ & $0.521^{\star \star \star}(0.367$ to 0.675$)$ \\
\hline \multicolumn{3}{|l|}{ Mother's education } \\
\hline \multicolumn{3}{|l|}{ No education ${ }^{\dagger}$} \\
\hline Primary & $1.837^{\star \star \star}(1.551$ to 2.123$)$ & 1.107 (0.933 to 1.282$)$ \\
\hline Secondary & $2.100^{\star \star \star}(1.771$ to 2.429$)$ & $1.122(0.952$ to 1.293$)$ \\
\hline Higher & $3.557^{\star \star \star}$ (2.521 to 4.593$)$ & 1.207 (0.926 to 1.489$)$ \\
\hline \multicolumn{3}{|l|}{ EAG states } \\
\hline \multicolumn{3}{|l|}{ Non-EAG ${ }^{\dagger}$} \\
\hline EAG & $0.374^{\star \star \star}(0.282$ to 0.466$)$ & $0.709^{\star \star \star}(0.574$ to 0.844$)$ \\
\hline \multicolumn{3}{|l|}{ Place of residence } \\
\hline \multicolumn{3}{|l|}{ Rural $^{\dagger}$} \\
\hline Urban & $0.673(0.232$ to 1.114$)$ & 0.988 (0.854 to 1.122$)$ \\
\hline \multicolumn{3}{|l|}{ Wealth index } \\
\hline \multicolumn{3}{|l|}{$\operatorname{Low}^{\dagger}$} \\
\hline Medium & $1.277^{\star \star}(1.108$ to 1.446$)$ & $1.173^{\star \star}(1.012$ to 1.335$)$ \\
\hline High & $1.386^{\star * *}(1.164$ to 1.609$)$ & 1.103 (0.921 to 1.286$)$ \\
\hline Constant & 2.824 (2.136 to 3.513$)$ & 0.567 (0.433 to 0.701$)$ \\
\hline
\end{tabular}

${ }^{*} \mathrm{p}<0.10,{ }^{* *} \mathrm{p}<0.05,{ }^{* * *} \mathrm{p}<0.001$.

†Reference category.

EAG, Empowered Action Group.

and school dropouts. ${ }^{31-35}$ In many occasions, unintended births result in neonatal mortality and infant mortality in India. $^{21} 36-38$

Since 1990s, several audacious steps have been taken by the government of India pertaining to more comprehensive, women-sensitive health programmes. Further, focus has been triggered towards a reproductive and child health programme (RCH) by shifting from target specific family planning. $\mathrm{RCH}$ has offered greater opportunity in working as well as learning from non-governmental organisations. However, the programme has suffered from lack of coverage, awareness and monitoring of the service 
Table 5 Association between birth intention and z-score for height for age (HAZ) and weight for age (WAZ): results from linear regression (beta coefficients)

\begin{tabular}{|c|c|c|}
\hline Covariates & HAZ & WAZ \\
\hline \multicolumn{3}{|l|}{ Birth intention } \\
\hline \multicolumn{3}{|l|}{ Intended $^{\dagger}$} \\
\hline Unintended & $-0.193^{\star \star}(-0.308$ to -0.077$)$ & $-0.172^{\star *}(-0.335$ to -0.010$)$ \\
\hline \multicolumn{3}{|l|}{ Children survival } \\
\hline \multicolumn{3}{|l|}{$1-2^{\dagger}$} \\
\hline $3-4$ & $-0.065(-0.220$ to 0.088$)$ & $-0.011(-0.229$ to 0.206$)$ \\
\hline $4+$ & $-0.105(-0.291$ to 0.080$)$ & $-0.003(-0.265$ to 0.259$)$ \\
\hline \multicolumn{3}{|l|}{ Sex of the child } \\
\hline \multicolumn{3}{|l|}{ Male $^{\dagger}$} \\
\hline Female & $-0.045(-0.138$ to 0.048$)$ & $-0.052(-0.155$ to 0.051$)$ \\
\hline \multicolumn{3}{|l|}{ Caste groups } \\
\hline \multicolumn{3}{|l|}{ General $^{\dagger}$} \\
\hline Other backward caste & $-0.157^{\star *}(-0.301$ to -0.013$)$ & $0.047(-0.155$ to 0.250$)$ \\
\hline Scheduled Caste & $-0.205^{\star \star}(-0.371$ to -0.038$)$ & $-0.130(-0.365$ to 0.104$)$ \\
\hline Scheduled Tribe & $-0.267^{\star \star}(-0.482$ to -0.052$)$ & $0.110(-0.193$ to 0.413$)$ \\
\hline No caste & $-0.814^{\star \star}(-1.467$ to -0.160$)$ & $-0.667(-1.696$ to 0.362$)$ \\
\hline \multicolumn{3}{|l|}{ Religion } \\
\hline \multicolumn{3}{|l|}{$\mathrm{Hindu}^{\dagger}$} \\
\hline Muslim & $0.077(-0.068$ to 0.224$)$ & $-0.022(-0.229$ to 0.184$)$ \\
\hline Others & $0.536^{\star \star \star}(0.238$ to 0.834$)$ & $0.333(-0.089$ to 0.756$)$ \\
\hline \multicolumn{3}{|l|}{ Mother's education } \\
\hline \multicolumn{3}{|l|}{ No education ${ }^{\dagger}$} \\
\hline Primary & $0.137^{*}(-0.019$ to 0.294$)$ & $0.163(-0.057$ to 0.384$)$ \\
\hline Secondary & $0.201^{\star \star}(0.049$ to 0.353$)$ & $0.183^{*}(-0.030$ to 0.398$)$ \\
\hline Higher & $0.360^{* \star}(0.115$ to 0.606$)$ & $0.435^{\star \star}(0.090$ to 0.780$)$ \\
\hline \multicolumn{3}{|l|}{ Place of residence } \\
\hline \multicolumn{3}{|l|}{ Rural $^{\dagger}$} \\
\hline Urban & $0.114^{*}(-0.020$ to 0.250$)$ & $-0.045(-0.235$ to 0.144$)$ \\
\hline \multicolumn{3}{|l|}{ EAG states } \\
\hline \multicolumn{3}{|l|}{ Non-EAG ${ }^{\dagger}$} \\
\hline EAG & $-0.025(-0.220$ to 0.170$)$ & $-0.117(-0.338$ to 0.103$)$ \\
\hline \multicolumn{3}{|l|}{ Wealth index } \\
\hline \multicolumn{3}{|l|}{ Low $^{\dagger}$} \\
\hline Medium & $0.108(-0.021$ to 0.237$)$ & $0.108(-0.072$ to 0.290$)$ \\
\hline High & $0.158^{*}(-0.004$ to 0.321$)$ & $0.285^{\star \star *}(0.055$ to 0.515$)$ \\
\hline Constant & $-1.587(-1.830$ to -1.344$)$ & $-1.911(-2.256$ to -1.566$)$ \\
\hline
\end{tabular}

${ }^{*} \mathrm{p}<0.10,{ }^{* *} \mathrm{p}<0.05,{ }^{* * \star} \mathrm{p}<0.001$.

†Reference category.

EAG, Empowered Action Group.

delivery. ${ }^{39}$ Therefore, the current study undermines the importance of the most affordable, available and accessible means of family planning to abate the unintended births. The programme should focus on highlighting the importance of family planning to increase the awareness among the population. Unlike the previous programme, there is a need for greater male involvement in decisionmaking for the choice of a suitable family planning method to avoid unintended births. ${ }^{40}$ The programme should also address the crucial indicators such as child marriage as well as early pregnancies. Furthermore, there should be proper monitoring and evaluation to track the 
progress of the service delivery so that in future, corrective action can be taken.

Further, the current study has various limitations like not including other child development indicators viz. education and their cognitive skills. Moreover, the 7-year duration of the survey is a longer duration when a woman's childbearing intention would have changed, thus, child healthcare and growth would not be so influenced by her previously stated intention to have children. Further, fathers' intention and family involvement would also have influenced child well-being. Moreover, variables related to mothers' occupation and health service utilisation are also not available in the dataset. Therefore, the study is only able to use a limited number of covariates for the statistical analysis.

Apart from these limitations, the study has provided an insight that unintended pregnancy is a serious issue for a country like India as it is related to adverse maternal and child health outcomes. Therefore, the present study contributes to the body of evidence supporting the fact that unintended pregnancy is not only about being concerned with fertility levels but also crucial for public health challenges.

\section{CONCLUSION}

This study provides clear evidence that the children born as unintended face serious health implications. As children are unintended, most of the mothers do not pay attention to them; and because of this behaviour, they receive inadequate immunisation and exclusive breast feeding during the early childhood development period. The same can be seen in children's physical development, as children from unintended births are more likely to be stunted and underweight. Children with poor physical development suffer from poor cognitive ability which affects their school performance and daily attendance. Moreover, unintended births may also cause neonatal mortality and infant mortality. Therefore, averting unwanted births at individual level enhances the well-being of women and children. There should be renewed and revitalised attempts to help couples, especially women, to achieve their reproductive goals and avoid unwanted pregnancy. Further, there is a need for affordable, accessible and available means of family planning to reduce the unintended births.

Acknowledgements This research is part of MPhil dissertation conducted within the International Institute for Population Sciences. I thank my supervisor Dr Preeti Dhillon of the Department of Mathematical Demography for their continuous insight and guidance during my research.

Contributors All authors, PC, MKG and MIKS contributed to conceptualising, writing and editing this paper. Data analysis was performed by PC and MKG.

Funding The authors have not declared a specific grant for this research from any funding agency in the public, commercial or not-for-profit sectors.

Competing interests None declared.

Patient consent for publication Not required.
Ethics approval This research paper is based on secondary data which are available in the public domain for research use, therefore, there is no formal approval from the institutional review board required.

Provenance and peer review Not commissioned; externally peer reviewed.

Data availability statement Data are available in a public, open-access repository. The data are downloaded from IHDS website. They are open-access data, and anyone can download these data for research. The link is: https://ihds. umd.edu/data/data-download.

Open access This is an open access article distributed in accordance with the Creative Commons Attribution Non Commercial (CC BY-NC 4.0) license, which permits others to distribute, remix, adapt, build upon this work non-commercially, and license their derivative works on different terms, provided the original work is properly cited, appropriate credit is given, any changes made indicated, and the use is non-commercial. See: http://creativecommons.org/licenses/by-nc/4.0/.

ORCID iDs

Poulomi Chowdhury http://orcid.org/0000-0001-5640-3077

Md Illias Kanchan Sk http://orcid.org/0000-0002-9598-9119

\section{REFERENCES}

1 CDC. Centre for disease control and prevention. unintended pregnancy. Available: https://www.cdc.gov/reproductivehealth/ contraception/unintendedpregnancy/index.htm

2 Blanc A. Unwanted fertility in Latin America and the Caribbean, 1982: 156-62.

3 Bongaarts JJP. Review D. the measurement of wanted fertility, 1990: 487-506.

4 Ford N. Reproductive change in developing countries: insights from the world fertility survey, 1986.

5 Survey WF, UNDol E. Fertility behaviour in the context of development: evidence from the world fertility survey: United nations Pubns, 1987.

6 Singh A, Singh A, Mahapatra B. The consequences of unintended pregnancy for maternal and child health in rural India: evidence from prospective data. Matern Child Health J 2013;17:493-500.

7 Gipson JD, Koenig MA, Hindin MJ. The effects of unintended pregnancy on infant, child, and parental health: a review of the literature. Stud Fam Plann 2008;39:18-38.

8 Altfeld S, Handler A, Burton D, et al. Wantedness of pregnancy and prenatal health behaviors. Women Health 1998;26:29-43.

9 Than LC, Honein MA, Watkins ML, et al. Intent to become pregnant as a predictor of exposures during pregnancy: is there a relation? $J$ Reprod Med 2005;50:389.

10 Eggleston E. Unintended pregnancy and women's use of prenatal care in Ecuador. Soc Sci Med.

11 Magadi MA, Madise NJ, Rodrigues RN. Frequency and timing of antenatal care in Kenya: explaining the variations between women of different communities. Soc Sci Med

12 AJJPs G. Premarital childbearing unwanted fertility and maternity care in Kenya and Namibia. Population Studies 1998;52:21-34. doi:10.1080/0032472031000150156

13 Marston C, Cleland J. Do unintended pregnancies carried to term lead to adverse outcomes for mother and child? an assessment in five developing countries. Popul Stud 2003;57:77-93.

14 Sedgh G, Singh S, Hussain R. Intended and unintended pregnancies worldwide in 2012 and recent trends. Stud Fam Plann 2014;45:301-14.

15 World Health Organisation. Preventing Unsafe Abortion, 2019. Available: https://www.who.int/news-room/fact-sheets/detail/ preventing-unsafe-abortion

16 Logan C, Holcombe E, Manlove J. The consequences of unintended childbearing. Washington, DC: Child Trends and National Campaign to Prevent Teen Pregnancy, 2007: 28. 142-51.

17 Singh A, Singh A, Thapa S. Adverse consequences of unintended pregnancy for maternal and child health in Nepal. Asia Pac J Public Health 2015;27:NP1481-91.

18 Lindberg L, Maddow-Zimet I, Kost K, et al. Pregnancy intentions and maternal and child health: an analysis of longitudinal data in Oklahoma. Matern Child Health J 2015;19:1087-96.

19 Hall JA, Benton L, Copas A, et al. Pregnancy intention and pregnancy outcome: systematic review and meta-analysis. Matern Child Health J 2017;21:670-704.

20 Singh A, Upadhyay AK, Singh A, et al. The association between unintended births and poor child development in India: evidence from a longitudinal study. Stud Fam Plann 2017;48:55-71. 
21 Singh A, Chalasani S, Koenig MA, et al. The consequences of unintended births for maternal and child health in India. Popul Stud 2012;66:223-39.

22 ICPSR. Indian human development survey, 2011. Available: https:// www.icpsr.umich.edu/icpsrweb/DSDR/studies/34480

23 World Health Organisation. WHO vaccine-preventable diseases: monitoring system: 2009 global summary. World Health Organization, 2009.

24 Staff WHO, Organization WH, UNICEF., UNAIDS. Global strategy for infant and young child feeding: World Health organization, 2003.

25 World Health Organisation. Child growth standards, 2007. Available: https://www.who.int/childgrowth/software/en/

26 Delgado-Rodríguez M, Gómez-Olmedo M, Bueno-Cavanillas A, et al. Unplanned pregnancy as a major determinant in inadequate use of prenatal care. Prev Med 1997;26:834-8.

27 Kost K, Landry DJ, Darroch JE. Predicting maternal behaviors during pregnancy: does intention status matter? Fam Plann Perspect 1998;30:79-88.

28 Doskoch P. Unplanned pregnancy linked to poor child health in India Int Perspect Sex Reprod Health 2012;38:223.

29 Jena K, Issue D. Female foeticide in India: a serious challenge for the Society, 2008: 8-17.

30 Mishra V, Roy TK, Retherford RD. Sex differentials in childhood feeding, health care, and nutritional status in India. Popul Dev Rev 2004;30:269-95. doi:10.1111/j.1728-4457.2004.013_1.x

31 Gashu D, Stoecker BJ, Bougma K, et al. Stunting, selenium deficiency and anemia are associated with poor cognitive performance in preschool children from rural Ethiopia. Nutr $J$ 2015;15:38

32 Crookston BT, Dearden KA, Alder SC, et al. Impact of early and concurrent stunting on cognition. Matern Child Nutr 2011;7:397-409.

33 Black RE, Allen LH, Bhutta ZA, et al. Maternal and child undernutrition: global and regional exposures and health consequences. Lancet 2008;371:243-60.

34 Fernald LCH, Kariger P, Hidrobo M, et al. Socioeconomic gradients in child development in very young children: evidence from India, Indonesia, Peru, and Senegal. Proc Natl Acad Sci U S A 2012;109 Suppl 2:17273-80.

35 Connell M. Evaluating the effects of nutritional intake during adolescence on educational attainment and labor market earnings as an adult, 2018.

36 LawnJE C. 4 million neonatal deaths: when? where? why? Lancet 2005:5-11.

37 Joyce TJ, Kaestner R, Korenman S. The effect of pregnancy intention on child development. Demography 2000;37:83-94.

38 Chalasani S, Casterline JB, Koenig MA, eds. Consequences of unwanted childbearing: a study of child outcomes in Bangladesh. New York: Annual meeting of the Population Association of America, 2007.

39 Visaria L, Jejeebhoy S, TJIfpp M. From family planning to reproductive health: challenges facing India, 1999: S44-9.

40 Muttreja P, Singh S, SJTljomr S. Family planning in India: the way forward. Indian J Med Res 2018;148:S1-9. doi:10.4103/ijmr. IJMR_2067_17 